\title{
The neuromuscular features of acromegaly: a clinical and pathological study
}

\author{
AA KHALEELI, RD LEVY, RHT EDWARDS, G McPHAIL, KR MILLS, JM ROUND, \\ DJ BETTERIDGE
}

From the Departments of Medicine \& Endocrinology, University College London, School of Medicine, and The Rayne Institute, London, UK

SUMMARY A study of the neuromuscular features of acromegaly was performed in six patients. Clinical assessment was supplemented by quadriceps force measurements, plasma creatine kinase (CK) activities, electromyography (EMG) and nerve conduction studies. Muscle mass was measured by urinary creatinine/height indices (CHI) and cross sectional area (CSA) of thighs and calves on computed tomography. Quadriceps force/unit cross sectional area was derived. Needle biopsies of vastus lateralis were studied by histochemical and ultrastructural methods. Mean fibre area (MFA) and fibre type proportions were measured. Most of the subjects studied had muscle pain and proximal muscle weakness confirmed by quadriceps force measurements. This occurred in the absence of muscle wasting, as shown by cross sectional area measurements and normal or raised creatinine/height indices. "Myopathic" features were demonstrated by needle biopsy in half the patients and occasionally by electromyography and raised plasma creatine kinase activity. Abnormalities on needle biopsy included variation in fibre size, type 2 fibre atrophy and large type 1 MFA relative to type 2 MFA. Electronmicroscopy showed the non-specific findings of increased glycogen accumulation, excess lipofuscin pigment and myofilament loss.

There have been few systemic studies of the neuromuscular features of acromegaly. ${ }^{2}$ Muscle weakness in association with well developed musculature has been described, ${ }^{2}$ as has proximal muscle wasting. ${ }^{2}$ Acromegaly is a well-known cause of entrapment neuropathies, especially median nerve compression in the carpal tunnel..$^{34} \mathrm{~A}$ pituitary adenoma by its local effects may cause hormonal deficiencies such as hypothyroidism, which itself may cause "myopathy".

Hypertrophied fibres have been described in acromegaly. ${ }^{18}$ These studies were performed before the full significance of differences in fibre size from different muscle groups was recognised. ${ }^{9}$ Thus half the patients had biopsies from the deltoid and half from the quadriceps muscles making interpretation difficult. Recently an innovation has allowed accurate rapid measurements of mean fibre areas using

Address for reprint requests: AA Khaleeli, Academic Unit of Diabetes and Endocrinology, Archway Wing, Whittington Hospital, Highgate, London N19 5NF, UK.

Received 6 March 1984. Accepted 24 March 1984 electronic planimetry ${ }^{10}$ and subtle changes in type 2 mean fibre area (MFA) in endocrine myopathies have been detected. ${ }^{11}$ The needle biopsy technique ${ }^{12}$ together with strain gauge techniques to measure strength $^{13}$ and qualitative and quantitative measures of skeletal muscle on computed tomography scanning (CT $)^{14}$ has allowed the quadriceps to be extensively and rapidly investigated. Using these techniques, quadriceps force can be related to muscle bulk on CT scan to assess whether muscle weakness in acromegaly occurs in the presence of increased, normal or decreased bulk. The above techniques have been used to make a detailed systemic study of the neuromuscular features of acromegaly.

\section{Patients}

Six patients with typical clinical and endocrinological features of acromegaly were studied. Table 1 summarises the clinical details at the time of the study but all patients had had previously raised growth hormones $(\mathrm{GH})$ levels which did not suppress during a 50 gram oral Glucose Tolerance Test (GTT). All patients had had acral enlargement and excessive sweating before therapy. Three patients had had transethmoidal hypophysectomies and their medical details are given in table 1. 
Table 1 Clinical \& endocrinological features of six acromegalic patients

\begin{tabular}{|c|c|c|c|c|c|c|c|}
\hline & Normal range & $1(M)$ & $2(F)$ & $3(F)$ & $4(F)$ & $5(F)$ & $6(M)$ \\
\hline $\begin{array}{l}\text { Highest blood pressure } \\
\text { mm Hg }\end{array}$ & $\begin{array}{l}150 / 90 \mathrm{~mm} \mathrm{Hg} \\
\text { or below }\end{array}$ & $210 / 130$ & $200 / 110$ & $150 / 90$ & $200 / 100$ & $200 / 125$ & $170 / 100$ \\
\hline Visual field defect & - & Yes & Yes & No & No & No & No \\
\hline $\begin{array}{l}\text { Intrasellar (I) or } \\
\text { extrasellar (E) tumour } \\
\text { on CT scan }\end{array}$ & - & E (operated) & $\mathbf{E}$ & I & $\begin{array}{l}\text { Empty large } \\
\text { fossa }\end{array}$ & I & I \\
\hline $\begin{array}{l}\text { Cardiomegaly (CXR) } \\
\text { Fasting \& } 2 \text { hr Plasma } \\
\text { Glucose (50G GTT) }\end{array}$ & 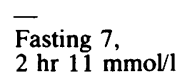 & $\begin{array}{l}\text { Yes } \\
10 \cdot 4,14 \cdot 7\end{array}$ & $\begin{array}{l}\text { No } \\
5 \cdot 2,6 \cdot 9\end{array}$ & $\begin{array}{l}\text { No } \\
4 \cdot 1,4\end{array}$ & $\begin{array}{l}\text { Yes } \\
4 \cdot 4,5 \cdot 0\end{array}$ & $\begin{array}{l}\text { Yes } \\
5 \cdot 2,6 \cdot 7\end{array}$ & $\begin{array}{l}\text { Yes } \\
5 \cdot 0,6 \cdot 2\end{array}$ \\
\hline $\begin{array}{l}\text { GH *suppression during } \\
\text { GTT (lowest value in } \\
\text { brackets) }\end{array}$ & $\mathrm{mU} / \mathrm{L}$ & Yes $(2.5)$ & $\mathrm{No}(80)$ & Yes (1) & $\mathrm{No}(54)$ & & $\mathrm{No}(36)$ \\
\hline $\begin{array}{l}\text { Serum thyroxine } \\
\text { Serum prolactin }\end{array}$ & $\begin{array}{l}70-160 \mathrm{nmol} / \mathrm{l} \\
360 \mathrm{MU} / \mathrm{l}\end{array}$ & $\begin{array}{l}100 \\
50\end{array}$ & $\begin{array}{l}124 \\
170\end{array}$ & 94 & & & $\begin{array}{l}\text { No }(30) \\
84 \\
5000\end{array}$ \\
\hline $\begin{array}{l}\text { Serum prolactin } \\
\text { Serum FSH }{ }^{*}\end{array}$ & $\begin{array}{l}360 \mathrm{MU} / 1 \\
\text { Menopausal } \\
\text { 35- I.U/L }\end{array}$ & - & 36 & $\begin{array}{r}50 \\
1\end{array}$ & $\begin{array}{l}50 \\
38\end{array}$ & $\begin{array}{r}121 \\
40\end{array}$ & $4 \dagger$ \\
\hline Serum $\mathrm{LH}^{*}$ & $\begin{array}{l}\text { Menopausal } \\
15-20 \mathrm{I} . \mathrm{U} / \mathrm{L}\end{array}$ & - & 17 & 1 & 25 & 19 & $4 \dagger$ \\
\hline $\begin{array}{l}\text { Previous surgery }(\mathrm{s}) \text { or } \\
\text { radiotherapy }(\mathrm{R}) \text { or } \\
\text { bromocryptine }(\mathrm{B}-\mathrm{mg})\end{array}$ & & $\begin{array}{l}\text { Yes (all 3) } \\
\text { B30/30 }\end{array}$ & $\begin{array}{l}\text { Yes (S \& B) } \\
\text { B20/20 }\end{array}$ & Yes (S) & $\begin{array}{l}\text { Yes (B) } \\
\text { B10/10/5 }\end{array}$ & $\begin{array}{l}\text { Yes (B) } \\
\text { B10/10 }\end{array}$ & No \\
\hline $\begin{array}{l}\text { Hormone replacement. } \\
\text { H=hydrocortisone. } \\
\text { T4= thyroxine (mg) }\end{array}$ & & $\mathrm{H} 20 / 10 \mathrm{~T} 40.3$ & $\mathrm{H} 10 / 5$ & $\begin{array}{l}\mathrm{H} 20 / 20 / 10 \\
\mathrm{~T} 40.3\end{array}$ & Nil & Nil & Nil \\
\hline
\end{tabular}

*At time of study (All patients had raised GH levels not suppressing during oral GTT originally)

†Normal values for male (plasma testosterone $294 \mathrm{pmol} / \mathrm{l}$ normal $170-550 \mathrm{pmol} / \mathrm{l}$ )

The sole patient with diabetes (patient 1) was stable on tolbutamide $500 \mathrm{mg}$ tds. The mean height of our patients was $168 \cdot 2 \mathrm{~cm}$ (range $150-188 \mathrm{~cm}$ ), their mean weight $91 \cdot 2$ $\mathrm{kg}$ (range $54 \cdot 3 \mathrm{~kg}-182 \mathrm{~kg}$ ) and their mean age 65 years (range 43-78 years). In patient 1 the disease had begun at the age of 16 years and this patient attained a height of 188 $\mathrm{cm}$. His tumour was unaffected by therapy and he later developed the features of acromegaly as well as his original features of gigantism.

\section{Materials and methods}

In each patient a detailed history and examination included special enquiry for neuromuscular features. Every patient gave informed consent for all procedures performed including written consent for needle biopsy of skeletal muscle. The plasma creatine kinase $(\mathrm{CK})$ was estimated on two or more occasions during hospital admission after a period of rest and before exercise testing. Boehringer kits with a glutathione activator were used to measure plasma creatine kinase on unhaemolysed blood at $37^{\circ} \mathrm{C}$. Quadriceps force measurements ${ }^{13}$ were made and the maximum voluntary contraction (MVC) of the stronger limb taken as the best of three separate efforts. Conventional concentric needle (Disa type BK 53) electromyography of the quadriceps (vastus medialis) was performed in four patients. The technique has been described elsewhere. ${ }^{15}$ In addition, sensory and motor conduction velocities in the median and ulna nerves were measured.

In all patients needle biopsy of the lateral muscle mass of the thigh was performed ${ }^{12}$ and the muscle treated as previously described for histochemistry, fibre type, MFA (counting fifty fibres of each fibre type) and electronmicroscopy. ${ }^{15}$ To assess total muscle mass, 24 hour urinary creatinine excretion was measured while on a creatine free diet. The diet commenced three days before urine collection. In five patients two separate collections were made. Care was taken to ensure complete collection and all collections occurred in hospital. Urinary creatinine/height index (CHI) expressed as a percentage of that expected for ideal body weight for each sex was used. ${ }^{16}{ }^{17}$ A creatinine coefficient of $23 \mathrm{mg} / \mathrm{kg}$ was used for males and $18 \mathrm{mg} / \mathrm{kg}$ for females. CT scans of the thighs and calves were performed on four patients using a Phillips scanner and cross sectional area was measured as described. ${ }^{14}$ This was compared with matched controls. The control group comprised five females and five males whose mean age was 58 years. The female mean height was $1.70 \pm 0.09 \mathrm{~m}$ and mean weight $62 \cdot 5-7 \cdot 2 \mathrm{~kg}$. The mean height of the males was 1.77 $\pm 0.09 \mathrm{~m}$ and their mean weight $75.9 \pm 12 \cdot 3 \mathrm{~kg}$.

\section{Results}

Table 2 summarises the neuromuscular features of our patients and the results of muscle investigations other than the CT scans and needle biopsy findings. It can be seen that lower limb muscle pain and proximal muscle weakness were common. In patient 1 previous hip surgery and subsequent immobility were undoubtedly major factors in the weakness observed, but this patient did have a raised CK level. Carpal tunnel syndrome and sciatic pain were prominent features in our patients and two patients had surgical decompression of the median nerve at the wrist.

Quadriceps weakness was common on force measurements. The same control group of 10 healthy subjects was used. The mean quadriceps 
Table 2 Summary of neuromuscular features \& investigations in 6 acromegalic patients

\begin{tabular}{|c|c|c|c|c|c|c|c|}
\hline & \multicolumn{6}{|c|}{ Acromegalic patients } & \multirow[t]{2}{*}{ Normal } \\
\hline & 1 & 2 & 3 & 4 & 5 & 6 & \\
\hline Muscle pain (site) & No & Yes (L) & Yes (B) & Yes (L) & Yes (A) & No & \\
\hline Proximal weakness (sign) & Yes (L) & Yes (B) & Yes (L) & No & No & No & \\
\hline Muscle wasting & No & Yes (L) & No & No & No & No & \\
\hline Carpal tunnel & No & Yes & Yes & No & Yes & No & \\
\hline Sciatic pain & No & Yes & Yes & No & No & No & \\
\hline Plasma CK & $198(3)$ & $27(2)$ & $10(2)$ & $27(2)$ & $55(2)$ & $59(4)$ & $10-120(\mathrm{IU} / \mathrm{l})$ \\
\hline M.V.C. quadriceps (Newtons) & 283 & 246 & 285 & 298 & 496 & 427 & \\
\hline$\%$ LLN $^{*}$ for body weight & $25 \%$ & $62 \%$ & $65 \%$ & $110 \%$ & $95 \%$ & $123 \%$ & \\
\hline EMG & - & Normal & Normal & Myopathic & Normal & - & \\
\hline Nerve conduction & - & SAP & Normal & Normal & $\begin{array}{l}\text { Delayed } \\
\text { (Median } \\
\text { nerve) }\end{array}$ & - & \\
\hline Creatinine height index $\%$ & $66 \%(2)$ & $118 \%(1)$ & $116 \%(2)$ & $81 \%(1)$ & $\begin{array}{l}\text { nerve) } \\
138 \%(20)\end{array}$ & $113 \%(2)$ & $90-110 \%$ \\
\hline
\end{tabular}

$\mathrm{L}=$ Lower limb, $\mathrm{A}=$ Arm, B = Both.

Numbers in brackets indicate number of estimations, mean quoted.

Expressed as \% of expected creatinine/height if body weight ideal ${ }^{17}$

${ }^{*}$ LLN $=$ Lower limit of normal ${ }^{13}$

$\mathrm{SAP}=$ reduced sensory action potentials in median, ulna and radial nerve.

MVC of these age matched controls was $120 \pm 27 \%$ of the lower limit of normal using normal young subjects. ${ }^{13}$ The lower limit of normal is defined as two standard deviations below the predicted normal for body weight. Allowing for age, three of our acromegalic patients were weak.

The EMG and nerve conduction findings are summarised (table 2). In each patient the abductor pollicis brevis, biceps brachialis and vastus medialis were sampled. Changes compatı!'e with a myopathy occurred in only one patient. Evidence of denervation was not detected, even in the patient whose needle biopsy suggested fibre grouping (patient 2). This patient had mild reduction in sensory action potentials in median, ulna and radial nerves but she was elderly. The urinary $\mathrm{CHI}$ were normal or increased especially when allowances for age were made..$^{18}$ Patient 1 who was the weakest subject in the

Table 3 Needle biopsy findings of skeletal muscle in six acromegalic patients

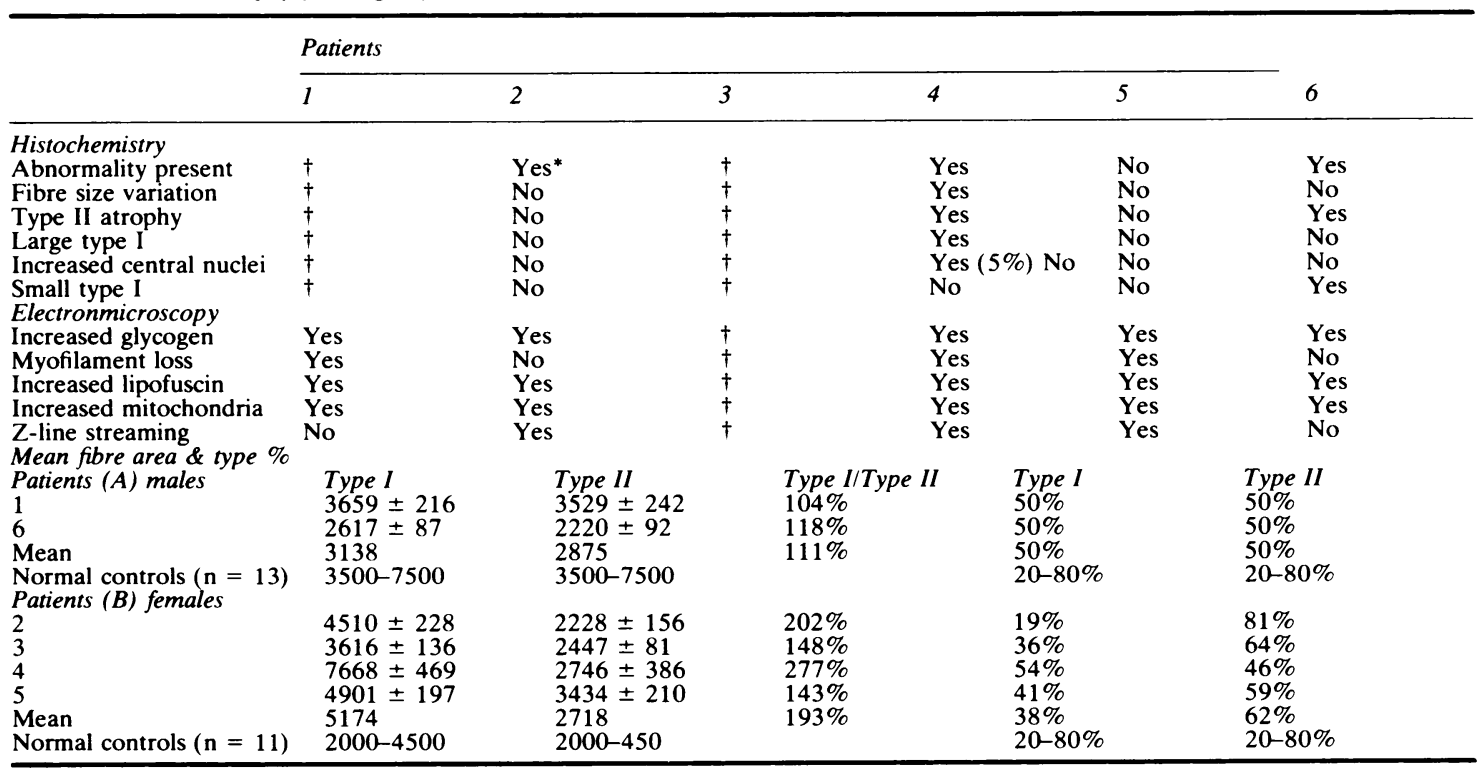

$*$ = suggestion of fibre grouping present

$\dagger=$ not estimated 


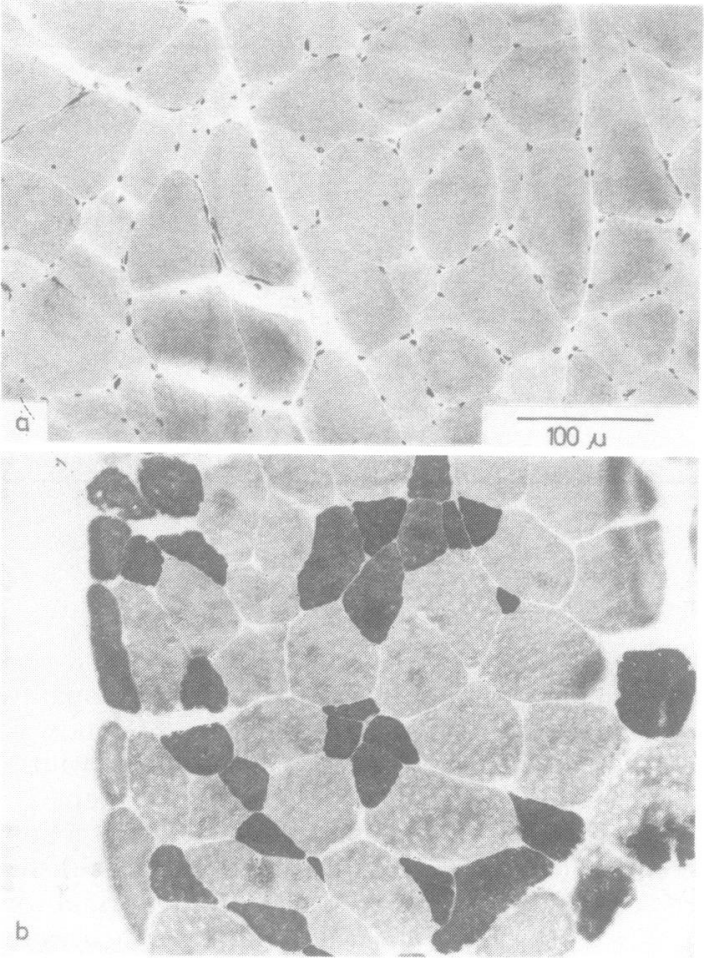

Fig 1 (a) Needle biopsy of the lateral muscle mass of the thigh showing variation in fibre size, hypertrophied and atrophic fibres and central nuclei. $H$ \& E stain, magnification $\times$ 40. (b) Myosin ATPase stain at pH 9.4 showing type II fibre atrophy (dark staining fibres) and variation in fibre size.

group was the only patient to show significant reduction in muscle mass. The probable cause of this was immobility from osteoarthritis of the hip.

Computed (CT) scans of the thighs were performed in patients 2-5 and none showed evidence of muscle wasting. The needle biopsy findings are summarised in table 3 . Figure 1 demonstrates the non-specific type II fibre atrophy, hypertrophied fibres, central nuclei and variation in fibre size which may be found. The latter finding is well illustrated by the variation in mean fibre area on the histogram (fig 2). Characteristic electromicroscopic findings are also shown in table 3 and depicted in fig 3 . As well as the findings described, satellite cells and contraction bands were noted in patient 2 . The mean fibre areas of the different types and the fibre percentages are shown in table 3 and our patients' fibre areas were compared with 24 normal healthy subjects (11 females and 13 males). Large type I MFA in the female group and type II MFA at the lower end of the normal range were typical.

\section{Discussion}

This study confirms that neuromuscular disorders are common in acromegaly. Half our patients had quadriceps weakness on force measurements even allowing for age. Poor motivation as the cause of weakness is unlikely because of the similarity of repeated force readings. Our patients did not have evident muscle wasting nor was it shown on computed tomography. The latter was particularly useful in assessing the obese patients. The urinary $\mathrm{CHI}$, a measure of muscle mass, was normal or raised in four patients, two of whom were weak. This was especially so when the ages of these patients were considered (range 61-78 years). Our findings are in keeping with previous observations that weak acromegalic subjects often appear relatively well muscled. ${ }^{2}$ This has been noted in pituitary gigantism. $^{19}$

Muscle pain was a striking feature, occurring in upper and lower limbs. The origin of this symptom may be difficult to determine. Three of our patients had carpal tunnel syndrome and two of these had symptoms of L5 nerve root compression. One of the latter patients had possible fibre grouping on her needle biopsy but the electromyogram was myopathic and showed no evidence of denervation.

Needle biopsy of skeletal muscle showed minor, non-specific, but obvious abnormalities on light microscopy in three patients. Large type I fibres, type II fibre atrophy, variation in fibre size and increased internal nuclei were all noted. These findings are common to other endocrine myopathies notably hypothyroidism ${ }^{20}$ and in keeping with previous work. ${ }^{2819}$ Mastaglia $^{8}$ noted large type I and type II fibres but only five out of his eight biopsies were from the same muscle making comparison difficult. In our patients type I MFA/type II MFA was much higher in the female patients $(193 \%)$ than in the male patients $(111 \%)$ and was at or above the upper limit of normal in each female. Type I MFA does tend to exceed type II MFA in elderly women, ${ }^{21}$ but our findings are in excess of the normal variation with age. In our males the type I MFA was at the lower limit of normal or below. Immobility was probably important in patient 1 but patient 6 was active. Patient 1 had also had a hypophysectomy and needed hydrocortisone. The possibility of gonadotrophin lack exists in patient 1 but in patient 6 with hyperprolactinaemia the plasma testosterone was normal.

Type 2 MFA were in the lower normal range or below it in four of our subjects. Histograms show the marked variation in type 2 MFA in patient 6 (fig $2 \mathrm{c}$ ). Mastaglia has previously noted that though type 2 atrophy was present other type 2 fibres might be 

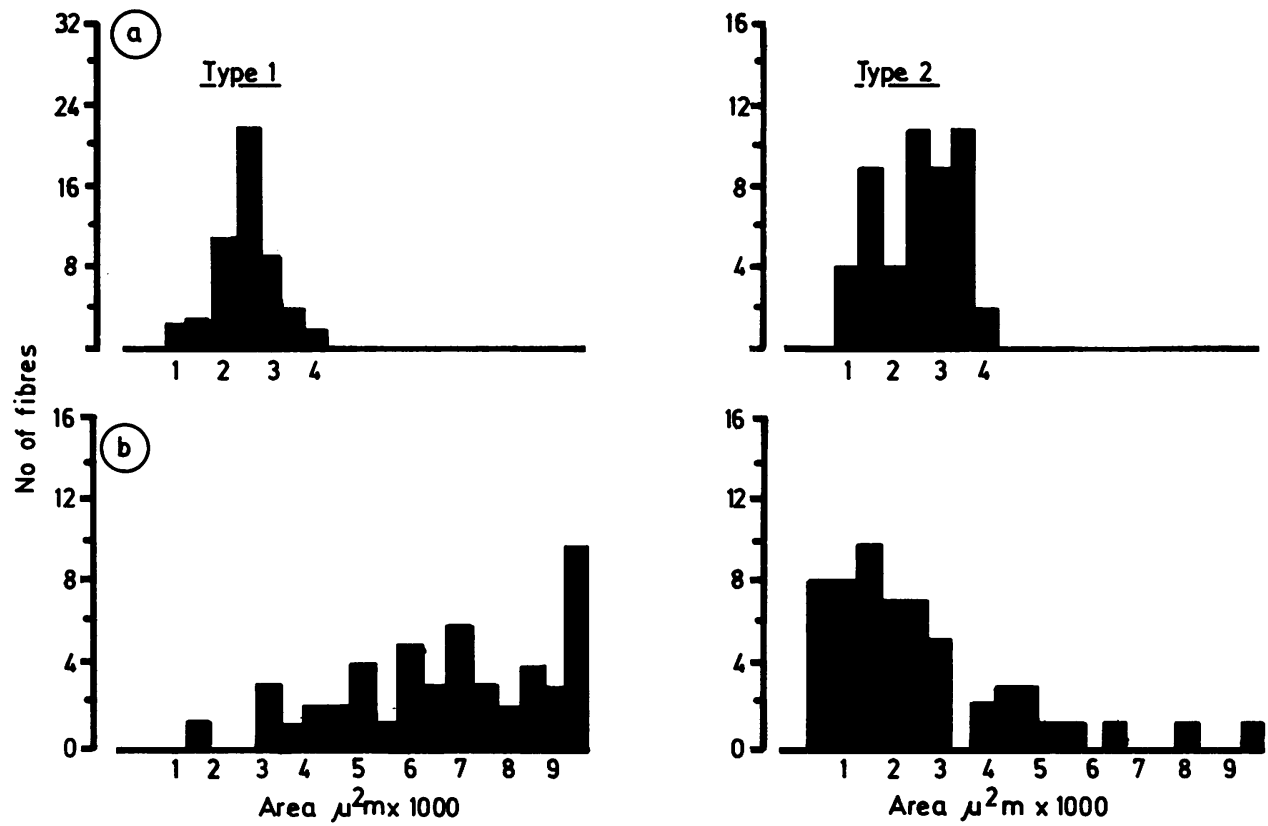

Fig 2 Histogram of skeletal muscle fibre areas obtained on needle biopsy of the lateral muscle mass of the thigh. (a) Normal subject. (b) Patient 4. Note marked variation in both type I and type II areas.
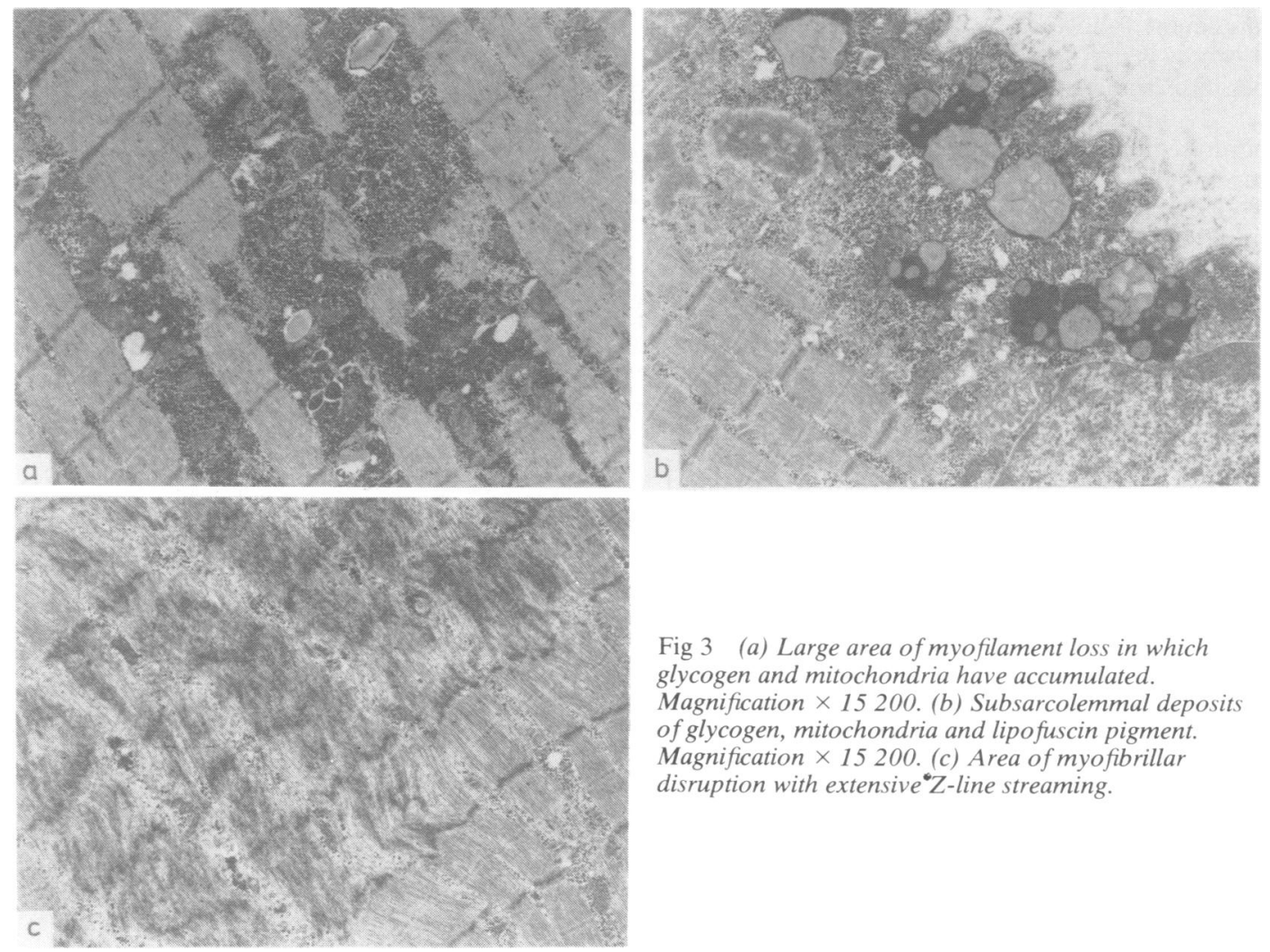

Fig 3 (a) Large area of myofilament loss in which glycogen and mitochondria have accumulated. Magnification $\times 15$ 200. (b) Subsarcolemmal deposits of glycogen, mitochondria and lipofuscin pigment. Magnification $\times 15$ 200. (c) Area of myofibrillar disruption with extensive $Z$-line streaming. 
large. ${ }^{19}$ Type 2 fibre atrophy is well known in hypothyroidism, ${ }^{112223}$ osteomalacia ${ }^{24}$ an thyrotoxicosis. ${ }^{23}{ }^{26}$ None of our patients had any evidence of the above disorders, and all were on conventional doses of hydrocortisone replacement. One of our patients had gonadotrophin lack and one had hyperprolactinaemia but so far as we know type 2 fibre atrophy has not been described in association with these disorders.

Ultrastructural changes such as increased subsarcolemmal glycogen accumulation, myofilament loss and increased lipofuscin pigment together with autophagic vacuoles have been well described by Mastaglia, ${ }^{8}$ as has the presence of satellite cells. Many of these findings are however non-specific and glycogen accumulation has been described in hypothyroid and corticosteroid myopathies. "1 152027 Thus many of the pathological changes seen in acromegaly may also occur in other endocrine disorders. It is possible that GH first stimulates an increase in cell size, possibly by increasing insulin levels. Insulin is known to increase cell size. ${ }^{28}$ The subsequent type 2 fibre atrophy may be a direct effect of prolonged GH excess or secondary to inactivity either occurring directly or in association with other hormone deficiencies. Speculation that fibre enlargement followed by atrophy may result from GH excess is not new. ${ }^{89}$ Half our patients had had hypophysectomies. Like Mastaglia ${ }^{8}$ we noted that type 2 fibre atrophy was commoner after hypophysectomy than before it but patient 6 was an exception.

Non-specific factors in acromegaly such as inactivity may be important in influencing muscle mass. They may result from the accompanying osteoarthritis, nerve compression, or chronic airways obstruction which are well known to occur. Certainly patients 1-3 were less active than patients 4-6.

Myopathic changes on electromyography and an elevated plasma CK activity were rare in our patients and in those of Lundberg $e ~ \mathrm{al}^{2}$ but Mastaglia $^{8}$ found the plasma $\mathrm{CK}$ activity helpful. Neuromuscular transmission was delayed in one of our patients and this was also reported by Lundberg et al. ${ }^{2}$ Lewis found evidence of a peripheral neuropathy in two patients with pituitary gigantism. ${ }^{19}$

In summary quadriceps weakness was confirmed on force measurements and associated with normal muscle bulk on CT scan. Urinary creatinine/height indices (CHI) were also prominent in our acromegalic patients. Needle biopsy from the same proximal muscle frequently showed evidence of "myopathy". Large type I mean fibre area/type II mean fibre area was found in female patients. Type 2 mean fibre area reduction and variation in fibre size were the most frequent findings. Further work should focus on the mechanisms by which these changes occur.

We particularly thank the nurses on the Metabolic unit, Dr DA Jones, and the Department of Chemical Pathology. The invaluable help of Miss Versia Patel is also gratefully acknowledged as is help from the Muscular Dystrophy Group of Great Britain and secretarial help from Miss AH Ziolkowki.

\section{References}

' Mastaglia FL, Barwick DD, Hall R. Myopathy in acromegaly. Lancet 1970;ii:907-9.

${ }^{2}$ Lundberg PO, Oosterman PO, Stalberg E. Neuromuscular signs and symptoms in acromegaly. In: Walton JN, Canal N, Scarlato G, eds. Muscle Disease. Proceedings of an International Congress, Milan. Amsterdam: Excerpta Medica, 1970:531-4.

${ }^{3}$ Skanse B. Carpal tunnel syndrome in myxoedema and acromegaly. Acta Chir Scand 1961;121:476.

${ }^{4}$ Gondring $\mathrm{H}$. The carpal tunnel syndrome in acromegaly. J Oklahoma Med Assoc 1966;59:274.

${ }^{5}$ Hoffman J. Weiterer Beitragzur lehre von der Tetanies. Deutsch z. Nervenheilk 1897;9:278.

- Debre R, Semelaigne G. Syndrome of diffuse muscular hypertrophy in infants causing athletic appearance: its connection with congential myodema. Am J Dis Child 1935; 50:1351-61.

' Klein I, Parker M, Sherbert R, Ayyer DR, Levy GS. Hypothyroidism presenting as muscle stiffness and pseudohypertrophy: Hoffman's Syndrome. Am J Med 1981;70:891-5.

${ }^{8}$ Mastaglia FL. Pathological changes in skeletal muscle in acromegaly. Acta neuropathol 1973;24:273-86.

9 Polgar J, Johnson MA, Weightman D, Appleton D. Data on fibre size in thirty-six human muscles. An autopsy study. J Neurol Sci 1973;19:307-18.

${ }^{10}$ Round JM, Jones DA, Edwards RHT. A flexible microprocessor system for the measurement of cell size. $J$ Clin Pathol 1982;35:620-4.

"Khaleeli AA, Gohil K, McPhail G, Round JM, Edwards RHT. Muscle morphology and metabolism in hypothyroid myopathy: effect of treatment. $J$ Clin Pathol 1983;36:519-26.

${ }^{12}$ Edwards RHT, Young A, Wiles CM. Needle biopsy of skeletal muscle in the diagnosis of myopathy and the clinical study of muscle function and repair. New Eng $J$ Med 1980;302:261-71.

${ }^{13}$ Edwards RHT, Young A, Hosking GP, Jones DA. Human skeletal muscle function: description of tests and normal values. Clin Sci 1977;52:283-90.

${ }^{14}$ Brenton DP, Edwards RHT, Grinrod SR, Tofts PS. Computerised $\mathrm{x}$-ray tomography to determine human skeletal muscle size and composition. J Physiol (Lond) 1981;317:3P.

${ }^{15}$ Khaleeli AA, Edwards RHT, Gohil K, McPhail G, Rennie MJ, Round JM, Ross EJ. Corticosteroid myopathy. A clinical and pathological study. Clin Endocrinol 1983;18:155-66. 
${ }^{16}$ Viteri FE, Alvarado J. The creatinine height index: its use in the estimation of the degree of protein depletion and repletion in protein calorie malnourished children. Paediatrics 1970;46:696-706.

${ }^{17}$ Bristrian BR, Blackburn GL, Sherman M, Scrimshaw NS. The therapeutic index of nutritional depletion in hospitalised patients. Surg Gynaecol Obstet 1975; 14:512-6.

18 Tzankoff SP, Norris AH. Effect of muscle mass decrease on age related BMR changes. J Appl Physiol 1977;43(6): 1001-6.

${ }^{19}$ Lewis PD. Neuromuscular involvement in pituitary gigantism. Br Med J 1972;2:499-500.

${ }^{20}$ McKeran RO, Slavin G, Ward P, Paul E, Mair WGP. Hypothyroid myopathy. A clinical and pathological study. J Pathol 1980;132:35-54.

${ }^{21}$ Aniansson A, Grimby G, Hedberg M, Krotkiewski M. Muscle morphology, enzyme activity and muscle strength in elderly men and women. Clin Physiol 1981;1:73-86.

${ }^{22}$ McKeran RO, Slavin G, Andrews TH, Ward P, Mair WGP. Muscle fibre type changes in hypothyroid myopathy. J Clin Pathol 1975;28:659-63.
${ }^{23}$ Wiles CM, Young A, Jones DA, Edwards RHT. Muscle relaxation rate, fibre type composition and energy turnover in hyper- and hypo-thyroid patients. Clin Sci 1979;57:375-84.

${ }^{24}$ Dastur DK, Gagrat BM, Wadia NH, Desai MM, Bharucha EP. Nature of muscle change in osteomalacia: light and electronmicroscope observations. J Pathol 1975;117:211-28.

${ }^{25}$ Young A, Brenton DP, Edwards RHT. Analysis of muscle weakness in osteomalacia. Clin Sci Mol Med 1978;54:31P.

${ }^{26}$ Ramsay I. Thyroid Disease and Muscle Dysfunction. London \& Tonbridge: Whitefriars Press, 1974:21-31.

${ }^{27}$ Vignos PJ Jr, Greene R. Oxidative respiration of skeletal muscle in experimental corticosteroid myopathy. $J$ Lab Clin Med 1973;81:365-77.

${ }^{28}$ Cheek DB, Graystone JE. Insulin and growth hormone: regulators of growth with particular reference to muscle. Kidney International 1978:317-21.

${ }^{29}$ Adams RD, Denny-Brown D, Pearson CM. Diseases of Muscle. A study in Pathology. New York: Hoeber, 1965:608. 